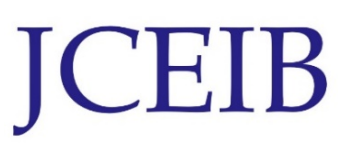

Open Access; Volume 1 pp. 83-96; March2017

(C) Universiti Malaysia Pahang Publisher

DOI: https://doi.org/10.15282/JCEIB-V1-04.31/3/2017/1.1.1

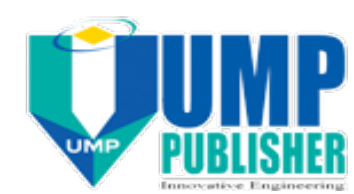

\title{
BIOLOGICAL SULFIDE OXIDATION AND ITS IMPACT ON CELL BIOMASS SYNTHESIS BY MESOPHILIC BACTERIUM BACILLUS CERUES (ATCC 14579)
}

\author{
Ahmad, M.M. ${ }^{\mathrm{a}^{*}}$, Azoddien, A.M. ${ }^{\mathrm{a}}$, Zahari, M. A.K.M ${ }^{\mathrm{a}}$, Seman, M. N and Jami, M. S. ${ }^{\mathrm{b}}$ \\ ${ }^{a}$ Faculty of Chemical and Natural Resources Engineering, Universiti Malaysia Pahang (UMP), Lebuhraya \\ Tun Razak, 26300 Gambang, Kuantan, Pahang, Malaysia \\ ${ }^{b}$ Faculty of Engineering, Department of Biotechnology Engineering, International Islamic University, \\ Malaysia (IIUM), Gombak, 50728, Kuala Lumpur, Malaysia. \\ * Corresponding author: E-mail: mmahmadu@gmail.com, \\ Tel.: +601136560301
}

\begin{abstract}
Inhibitory effects of hydrogen sulfide could either be due to toxicity to living tissue or precipitation of sulfide salts which inhibit its utilization for cell growth. Growth, is undoubtedly affected by certain conditions, among which are nutrient types and availability, as well as the operational parameters of the fermenting medium. In this study, Bacillus cereus (ATCC 14579) was tested for potential sulfide biodegradation in a suspended growth medium of orbital shake flasks using a single milieu composition under defined operational parameters. Growth and sulfide oxidation efficiency were measured spectrophotometrically under optimum physical conditions of $\mathrm{pH}$, temperature, acclimatization time and agitation. Sulfide reduction was overwhelmingly recorded at three different sulfide loading rates of $200 \mathrm{ppm} \mathrm{S}^{2-} \mathrm{L}^{-1} \mathrm{~d}^{-}$ 1, $300 \mathrm{ppm} \mathrm{S}^{2-} \mathrm{L}^{-1} \mathrm{~d}^{-1}$ and $500 \mathrm{ppm} \mathrm{S}^{2-} \mathrm{L}^{-1} \mathrm{~d}^{-1}$ with corresponding appreciable cell growth measured at $\mathrm{OD}_{600 \mathrm{~nm}}$. Results indicated that it was possible to realise sulfide removal efficiency of $95 \%$ to $99 \%$ using this strain in an orbital shake flask within 24 hrs, as well as $65 \%$ to $78 \%$ within the first $6 \mathrm{hrs}$ of inoculation. Overall, sulfide was reduced by $95 \%$ in $200 \mathrm{ppm}$ and $300 \mathrm{ppm}$, while $99 \%$ in $500 \mathrm{ppm}$, respectively. While, the corresponding exponential cell growth recorded was 3.91, 3.80 and 3.61 in 200 ppm, $300 \mathrm{ppm}$ and $500 \mathrm{ppm}$, respectively. This also translate to cell biomass synthesis (cell dry weight) of $0.61 \mathrm{~g} / \mathrm{L}, 0.58 \mathrm{~g} / \mathrm{L}$ and $0.50 \mathrm{~g} / \mathrm{L}$ in $200 \mathrm{ppm}, 500 \mathrm{ppm}$ and 300 $\mathrm{ppm}$. Based on this finding, it was clear that this inoculum can utilize different sulfide concentration for growth and biosynthesis; thus can be employed to treat sulfide contaminated wastewater in a suspended growth form under simple nutrient composition and operational conditions.
\end{abstract}

Keywords: Inhibition, Sulfide, Oxidation, Growth, Removal, Bacillus cereus

\subsection{INTRODUCTION}

Hydrogen sulfide $\left(\mathrm{H}_{2} \mathrm{~S}\right)$, or popularly sulfide, is a notable environmental pollutant considerably produced from numerous domestic and industrial wastewater sources. A toxicity effect of $\mathrm{H}_{2} \mathrm{~S}$ is not restricted to human and environment alone, but extended to microbial community capable of degrading it. It is highly toxic compounds that can be formed in any aqueous system which contains both organic matter and sulfate. 
Enning \& Garrelfs, (2014) reported that sulfide build up in industrial systems may cause several side effects like corrosion of concrete sewer pipes (mainly, due to microbiologically-induced corrosion by sulfate reducing bacteria), releasing unpleasant malodors, toxicity due to sulfide gas, and negative effect to subsequent wastewater. It is argued that wastewater containing sulfur compounds poses a challenging problem due to their recalcitrant nature of poor treatability, high toxicity and ecological aspects. Conventional physicochemical approach to sulfide removal need huge capital investment for handling and maintenance (Chung, et al.,, 1996; Kim, et al., 2008; Nur Hafizah et al.,, 2016; Tang, et al.,, 2009; Zytoon, et al., 2014).

Biological sulfide oxidation (BSO) on the contrary has the potential to give a perfect different option for the evacuation of low and high level sulfide from both fluid and gas streams, alongside the recuperation of sulfur (Liang, et al., 2015; Mathew, 2014). The predominance of either elemental sulfur or sulphate as the final product of the oxidation is mainly oxygen dependent mechanism; thus, in oxygen deficient conditions (micro-oxygenation), elemental sulfur is the main product (Diaz, et al.,, 2011; Wang, et al.,, 2016). Formation of elemental sulfur, sulfate or thiosulfate, depend mainly on oxygen concentration (Eq. 1,2,3,4), sulfide concentration and inoculum size (Krayzelova et al., 2015; Krayzelova, et al.,, 2014; Liang et al., 2015). Suspended form of BSO using chemolithotrophs in an aqueous medium is a popular option over the other BSO techniques which require exogenous carbon source and attachment surfaces (Zytoon, et al., 2014). In the initial phase of BSO, sulfite is produced through electron transport framework exchange from sulfide to the cell and subsequently to the terminal electron acceptor. In the most far reaching mechanism, sulfite oxidase exchanges electrons from sulfite specifically to cytochrome c with subsequent generation of an energy molecule, Adenosine triphosphate (ATP). Thereafter, sulfite oxidation is facilitated through an inversion action of an enzyme adenosine phosphosulfate reductase. This response gives rise to a strong phosphate bond which leads adenosine monophosphate (AMP) changed to adenosine diphosphate (ADP). At the point when thiosulfate is utilized as electron donor, it dissociated into sulfur and sulfite, both of which are then oxidized to sulfate (Tang, et al.,, 2009).

$$
\begin{aligned}
& 2 \mathrm{HS}^{-}+\mathrm{O}_{2} \rightarrow \mathrm{S}^{0}+2 \mathrm{OH}^{-} \\
& 2 \mathrm{HS}^{-}+2 \mathrm{O}_{2} \rightarrow \mathrm{S}_{2} \mathrm{O}_{3}{ }^{2-}+\mathrm{H}_{2} \mathrm{O} \\
& 2 \mathrm{HS}^{-}+3 \mathrm{O}_{2} \rightarrow 2 \mathrm{SO}_{3}{ }^{2-}+2 \mathrm{H}^{+} \\
& 2 \mathrm{HS}^{-}+4 \mathrm{O}_{2} \rightarrow 2 \mathrm{SO}_{4}{ }^{2-}+2 \mathrm{H}^{+}
\end{aligned}
$$

Sulfide oxidation rate is estimated based on the difference between the initial concentration $S_{o}$ and a concentration $S_{t}$ at a given time $t$ divided by $S_{o}$, while the percentage removal is determined by multiplying the outcome by 100 and is given as:

$$
R E(\%)=\left(S_{o}-S_{t} / S_{o}\right) x 100
$$


Bacillus cereus (ATCC 14579) $\beta$-hemolytic, spore-forming and facultative anaerobes, naturally found in soil and vegetation, growing under mesophilic temperature range of $20-45{ }^{\circ} \mathrm{C}$. Being a heterotroph, it possesses the ability to utilize nitrate as electron acceptor through autotrophic denitrification process (Borah \& Yadav, 2014; Bujang et al., 2013; Vinothini, et al., 2015). It was reported that some of these bacterial strains have been identified to anaerobically oxidize inorganic sulfur compounds such as sulfide, sulfur, thiosulfate and sulfite by using nitrate and nitrite as electron acceptor that is finally reduced to nitrogen gas (Fajardo et al., 2014; Li, et al., 2009; Moon, et al., 2004; Zhou et al., 2011). However, its application to BSO is rare or even unavailable. Growth pattern of this isolate is reported to be slowed with prolonged lag phase upon exposure to limiting factors popularly known as oxidative stress or stress phenomenon (Hornstra, et al., 2006; Mols \& Abee, 2011; Schagger, et al., 2004). The oxygen deficient nature of shake flasks medium of near anoxic was quite tolerated by this isolate that enable it to oxidize sulfide to appropriate form depending on the prevailing physicochemical conditions.

The present study was set to ascertain the novel experimentation of this new mesophilic bacterium to biological sulfide oxidation, which until now was rarely documented, although some significant discoveries were made related to growth optimization conditioned in different substrates medium. In addition to this, some findings were available on the use of this mesophilic bacterium in treatment of wastewaters laden with phenol, petrochemical effluent and some heavy metals. Pilot study related to sulfide oxidation under nutrient constrains and other operational physical parameters of orbital shake flasks for B. cereus growth and biosynthesis against different simulated sulfide concentrations is not reported elsewhere. However, simple as it may appear, it is believed this could serve as an indicator to achieving BSO in a cheap, simple and eco-friendly approach. Therefore, the finding from this work could be utilized to further sulfide oxidation research studies using this pure culture.

\section{Media and Bacterial Inoculum}

\subsection{MATERIALS AND METHOD}

The bacterial isolate used in this study was obtained from stock culture bank at the Faculty of Chemical Engineering, University Malaysia Pahang. Nutrient broth made up of peptone $(5 \%)$ and meat extract $(3 \%)$ was the media used for the initial growth and biodegradation experiment. And entire chemicals and nutrients used in this research were of analytical grade (grade (BD 234000, Merck (Malaysia) Sdn. Bhd)), hence need no further preparation.

\section{Microbiological preparation of the inoculum}

Enriched culture media was prepared in accordance with the manufacturer's guidelines. Typically, $8 \mathrm{~g}$ of nutrient broth was dissolved in $1000 \mathrm{ml}$ of deionized water in Schott bottles and shaken vigorously until it dissolved. The solution was then heated on a hot plate and sterilized in an autoclave at $121{ }^{\circ} \mathrm{C}$ for 15 minutes; the sterilized media was then placed in a water bath to cool the media to $47{ }^{\circ} \mathrm{C}$ before pouring into various $20 \mathrm{ml}$ sampling bottles. Inoculation of bacterial strain was done by suspending 1-3 loops from the stock culture (Shea et al. 2013) into a $20 \mathrm{ml}$ freshly prepared nutrient broth $10 \%\left(\mathrm{wv}^{1-}\right)$. The seeded culture was incubated at $37{ }^{\circ} \mathrm{C}$ for 24 
hours at a vigorous shaking of $180 \mathrm{rpm}$. After 24 hours, the inoculum was transferred into four $500 \mathrm{ml}$ Erlenmeyer flask containing $150 \mathrm{ml}$ nutrient broth $30 \%\left(\mathrm{vv}^{1-}\right)$ of the original volume of the shake flask (Standbury, et al. 1984). The samples were then placed inside a shaker and calibrated for agitation and temperature accordingly for each run. The experiments were run under the selected different ranges of nutrient concentration and residence/acclimatization time. All the processes were aseptically done inside a biological close cabinet to avoid contamination.

\section{Biodegradation studies}

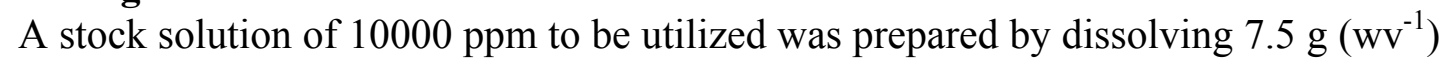
of Sodium sulfide $\left(\mathrm{Na}_{2} \mathrm{~S} .9 \mathrm{H}_{2} \mathrm{O}\right)$, in $1000 \mathrm{ml}$. From the stock solution, standard working simulated solutions of 200,300 and $500 \mathrm{ppm}$ were made through appropriate serial dilution (Emami, et al. 2004). To each of the three out of four Erlenmeyer flasks containing $150 \mathrm{ml} \mathrm{NB}$ and $20 \mathrm{ml}$ inoculum in a different concentration of sulfide in the range of 200, 300 and 500 ppm was added. The last flask was left without adding any sulfide which served a control and an additional fifth flask contained only nutrient broth was serving as a blank solution. A $0.5 \mathrm{M}$ buffer was used to maintain the medium $\mathrm{pH}$ at 8.5 , which is within the reported tolerable limit of this isolate as well to minimize the risk of $\mathrm{H}_{2} \mathrm{~S}$ gas release to the surrounding using. The entire four flasks with the exception of the blank solution were placed in an orbital shaker and adjusted to 180 rpm agitation, $36{ }^{\circ} \mathrm{C}$ for a day, while the last flask containing the blank solution was placed in a refrigerator and stored at $-4{ }^{\circ} \mathrm{C}$ to avoid any contamination. This experiment was repeated twice, to ensure the near accuracy of the observed results. The experimental set up in the shaker was as follows:

SAMPLE A: NB $180 \mathrm{ml}$ (blank)

SAMPLE B: NB $180 \mathrm{ml}+20 \mathrm{ml} \mathrm{NB}$ (Bacillus cereus)- control

SAMPLE C: NB $180 \mathrm{ml}+20 \mathrm{ml} \mathrm{NB}$ (Bacillus cereus) $+200 \mathrm{ppm}$

SAMPLE D: NB $180 \mathrm{ml}+20 \mathrm{ml} \mathrm{NB}$ (Bacillus cereus) $+300 \mathrm{ppm}$

SAMPLE E: NB $180 \mathrm{ml}+20 \mathrm{ml} \mathrm{NB}$ (Bacillus cereus) $+500 \mathrm{ppm}$

\section{Analytical procedure}

For growth and sulfide reduction analysis, $2.5 \mathrm{ml}$ aliquots were withdrawn at $0 \mathrm{hr}$ (initial), $1 \mathrm{hr}, 6 \mathrm{hr}, 12 \mathrm{hr}, 18 \mathrm{hr}$ and $24 \mathrm{hr}$. Growth was measured using UV-VIS Spectrophotometer (Hatachi, U-1800), at wavelength measurement of $600 \mathrm{~nm}$. This range is usually selected when a huge growth is expected so as to remain within the linear part of the relation between cell number and optical density without any need for a dilution to get a reliable value. Optical density is an indirect method for measuring bacterial growth which is based on the mechanism of light passing through a suspended medium. This concept is based on the fact that, as the cells grow the suspension become more turbid, hence the less percentage of light transmitted. However, UV-VIS spectrophotometer is working based on absorbance of light by the suspended medium, which is directly proportional to the increase in cell number and inversely proportional to percentage light transmission $(\% \mathrm{~T})$. Bacterial biomass or cell dried weight was determined by withdrawing $2 \mathrm{ml}$ sample from exponentially growing cells simultaneously with sample for OD analysis. Sample was centrifuged at 12,000 rpm for 15-20 minutes (Bratbak \& Dundas, 1984). Supernatant was discarded and solid washed in a saline solution and centrifuged again then oven dried at $100{ }^{\circ} \mathrm{C}-110{ }^{\circ} \mathrm{C}$ for $1 \mathrm{hr}$. The mass was measured and drying repeated until a stable 
weight was obtained, while methyl blue method in Hach (2400DR). Spectrophotometer was used to analyse sulfide (Kleinjan et al., 2005; Wang, et al., 2016).

\subsection{RESULTS AND DISCUSSION}

\section{Effect of Sulfide Concentration level on Bacterial Growth and Removal}

Results from Figures 1- 3 and Table 1-3 indicated the relative impact of different concentrations of hydrogen sulfide on the growth of B. cereus (ATCC 14579) measured as exponential cell growth and cell biomass increase. This also corresponds to appreciable sulfide reduction rate and utilization over a period of 24 hours experimentation. The mechanism of electron transport systems involved in BSO is utilized as a source of energy generation and biosynthesis. It was reported that, the rate of substrates conversion directly correspond to increase in cell density (Mora et al., 2014) which is affected by the sulfide loading rates, oxygen availability and product types (Alcántara et al., 2004), although the kinetic of BSO rate was reported to be a little more independent to oxygen concentration (Nielsen, et al., 2006). Microbial cell growth and biomass synthesis via sulfide utilization was shown to be favored more when the equilibrium shifted toward sulfur production, which usually occurs at low oxygen deficient medium and higher substrates concentration. During the first six hours of inoculation, an overwhelming growth (lag phase and early exponential growth) was recorded. This is attributed to response of the isolate to the new environmental conditions which were similar to the recently acclimatized one, as well present uptake of sulfide at an early stage during which it was used as electron donor to kick start exogenous carbon source utilization for biomass synthesis. However a slight decrease in growth was observed which could be attributed to accumulation of toxic waste due to aggressive metabolism at this early growth phase. This phase is characterized by synthesis of carbon source utilization genes(Schultz \& Kishony, 2013), but not ribosomal and amino acid biosynthesis genes which are responsible for cellular division and other late physiological mechanisms.

An appreciable sulfide utilization indicated by its oxidation was recorded within the first six hours of inoculation, with $130 \mathrm{ppm} / \mathrm{hr}(65 \%), 220 \mathrm{ppm} / \mathrm{hr}(73.33)$ and 390 $\mathrm{ppm} / \mathrm{hr}(78 \%)$ in $200 \mathrm{ppm}, 300 \mathrm{ppm}$ and $500 \mathrm{ppm}$, respectively. This was also compensated by an exponential cell biomass growth range of 2.62 to 3.91 and cell biomass increase measured by cell dry weight of 0.02 cell g/L to 0.59 cell g/L (Table 1-3).. Bacterial cell growth within the initial 6-8 hours of inoculation was shown to be the fastest phase due to efficient exchange of electrons between donors and acceptors as well as available nutrient source for rapid cell division and absence of accumulated metabolites residue that used to slowed cell growth (Azoddein, et al., 2016; Azoddein, et al., 2015). However, this sudden growth was followed by a decrease in cell growth probably due to inhibitory effects of free soluble form and undissociated $\mathrm{H}_{2} \mathrm{~S}$ which permeate cell membranes and form cross-links between polypeptide chains, thus altering cell proteins, coenzyme activities (Lorna Guerreroa et al., 2015). This activity is suspected to not only affecting cell growth but sulfide utilization, which may also cause a decreased in reduction rate and assimilation. Previous studies indicated growth during the first 4-6 hours of inoculation, which decreases mainly due to depletion of nutrients or accumulation of toxic metabolites in addition to the earlier stated reasons. The process of biological hydrogen sulfide oxidation to either sulfate or elemental sulfur through dissociation of $\mathrm{H}_{2} \mathrm{~S}$ to $\mathrm{HS}^{-}$or 
$\mathrm{S}^{2-}$ has been indicated to cause a rise in $\mathrm{pH}$ of the medium, eventually reversing the inhibitory effects, hence resumption of cell growth and sulfide oxidation drastically. As indicated from the result, that growth inhibition was found to be higher in sample containing 500 ppm sulfide concentration, while the least in 200 ppm (Fig. 4). This finding agrees well with other reported results regarding increase in inhibitory effects with increase in sulfide concentration (Greben, et al., 2005; Kousi, et al., 2015).

Furthermore, sulfide biological oxidation and cell biomass increase was consistently significant and sustained through the 24 hour period in all the three different concentrations. This may probably be due to sulfide being a complimentary nutrient source in addition to poorly rich medium consisting of only nutrient broth. Consequently, sulfide was significantly reduced by $190 \mathrm{ppm} / \mathrm{hr}(95 \%), 285 \mathrm{ppm} / \mathrm{hr}$ (95\%) and $495 \mathrm{ppm} / \mathrm{hr}(99 \%)$, in $200 \mathrm{ppm}, 300 \mathrm{ppm}$ and $500 \mathrm{ppm}$, respectively. This sulfide oxidation also corresponds to highest rates of growth observed (Figures13andTable1-3). It has been proven that microaerobic nature (low oxygen dosing level) coupled with high sulfide concentration facilitate sulfur formation (Janssen, et al., 1999; Tang, et al., 2009), thus high oxidation rate as in the case of $500 \mathrm{ppm}$, although, this was further affirmed in the finding by Van den et al., (1993) where they suggested high substrate concentration and low oxygen level favoring the sulfur formation. Overall, BSO was consistent in all the three different concentrations, although with some few variations which are believed to be due to the impact of the substance to metabolic activities of the isolate. This assertion could be deduced from the sulfide reduction rate in relation to cell biomass accumulation (CDW), which is given as the ration of concentration sulfide to cell biomass ( $\mathrm{ppm} \mathrm{H}_{2} \mathrm{~S} / \mathrm{g}$ cell). This inverse relationship indicated an increase in cell dry weight as sulfide concentration is further depleted, probably signaling sulfide uptake and assimilation by the growing and dividing cells (Table 1-3). This finding is supported by the (Abd.Aziz et al, 2016; Mosquera, et al., 2014).

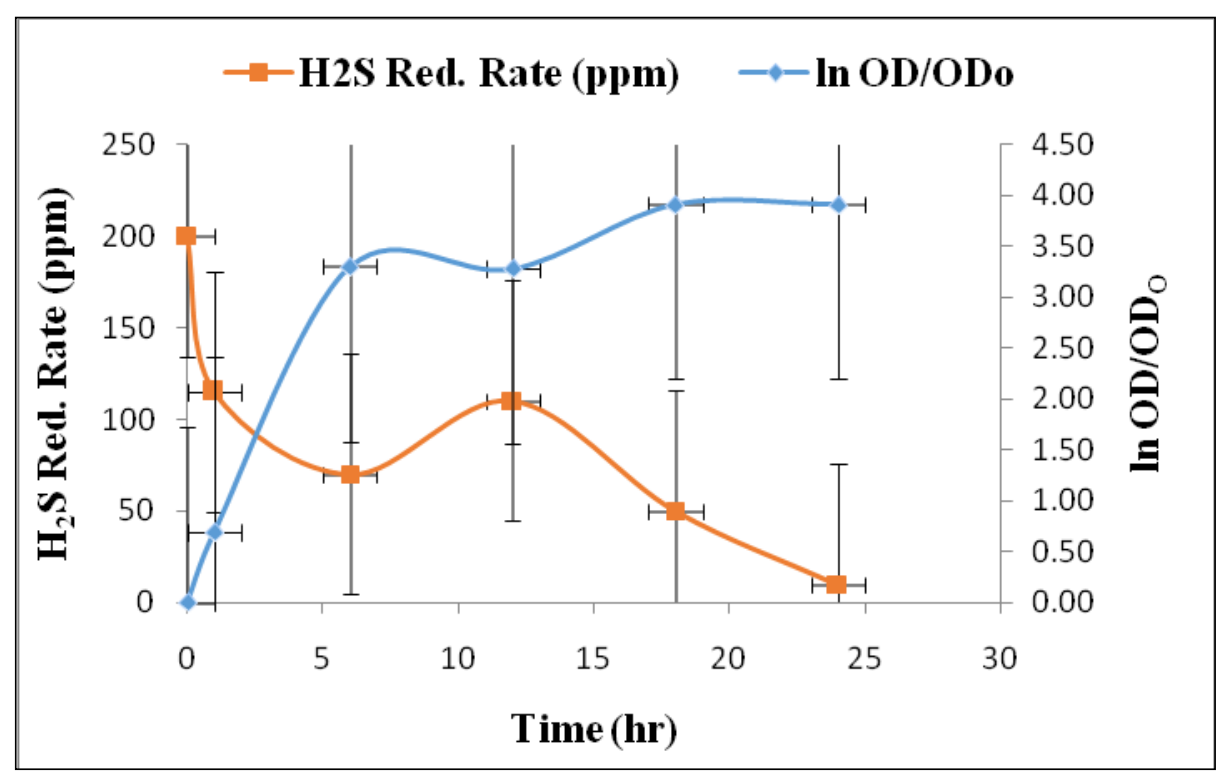

Figure 1: B. cereus (ATCC 14579) Growth \& Removal in 200 ppm sulfide concentration 
Table 1: Growth \& sulfide oxidation of Bacillus cereus (ATCC 14579) at $200 \mathrm{ppm}$

\begin{tabular}{ccccccc}
\hline Time & $\begin{array}{c}\mathrm{OD}(600 \\
\mathrm{nm})\end{array}$ & $\begin{array}{c}\text { Cell dry wt } \\
(\mathrm{g} / \mathrm{L})\end{array}$ & $\begin{array}{c}\text { Expon. Cell growth } \\
(\mathrm{lnOD} / \mathrm{OD})\end{array}$ & $\begin{array}{c}\mathrm{H}_{2} \mathrm{~S} \text { Red. Rate } \\
(\mathrm{ppm} / \mathrm{hr})\end{array}$ & $\begin{array}{c}\mathrm{H}_{2} \mathrm{~S} \text { Removal } \\
(\%)\end{array}$ & $\begin{array}{c}\mathrm{ppm} \mathrm{H}_{2} \mathrm{~S} / \mathrm{g} \\
\text { cell }\end{array}$ \\
\hline 0 & 0.03 & 0.01 & 0.00 & 200 & 0.00 & 0.00 \\
1 & 0.06 & 0.02 & 0.69 & 115 & 42.5 & 5,700 \\
6 & 0.81 & 0.32 & 3.30 & 70 & 65 & 220 \\
12 & 0.8 & 0.31 & 3.28 & 110 & 45 & 350 \\
18 & 1.5 & 0.59 & 3.91 & 50 & 75 & 80 \\
24 & 1.5 & 0.61 & 3.91 & 10 & 95 & 16 \\
\hline
\end{tabular}

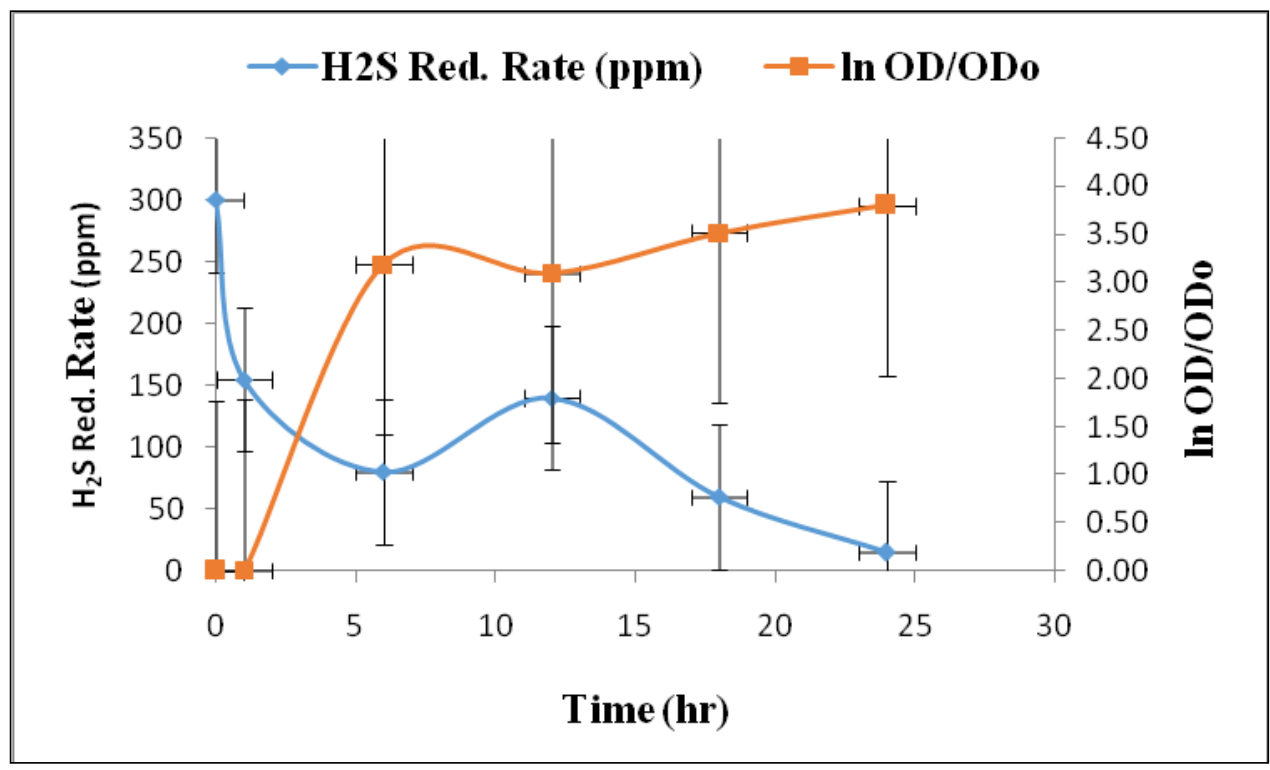

Figure 2: $B$. cereus (ATCC 14579) Growth \& Removal in 300 ppm sulfide concentration

Table 2: Growth \& ulfide oxidation of Bacillus cereus (ATCC 14579) at $300 \mathrm{ppm}$

\begin{tabular}{ccccccc}
\hline Time & $\begin{array}{c}\text { OD }(600 \\
\mathrm{nm})\end{array}$ & $\begin{array}{c}\text { Cell dry wt } \\
(\mathrm{g} / \mathrm{L})\end{array}$ & $\begin{array}{c}\text { Expon. Cell growth } \\
(\text { lnOD/ODo })\end{array}$ & $\begin{array}{c}\mathrm{H}_{2} \mathrm{~S} \text { Red. Rate } \\
(\mathrm{ppm} / \mathrm{hr})\end{array}$ & $\begin{array}{c}\mathrm{H}_{2} \mathrm{~S} \text { removal } \\
(\%)\end{array}$ & $\begin{array}{c}\mathrm{ppm} \mathrm{H}_{2} \mathrm{~S} / \mathrm{g} \\
\text { cell }\end{array}$ \\
\hline 0 & 0.03 & 0.01 & 0.00 & 300 & 0.00 & 0.00 \\
1 & 0.02 & 0.01 & 0.01 & 155 & 48.33 & 15,500 \\
6 & 0.73 & 0.28 & 3.19 & 80 & 73.33 & 280 \\
12 & 0.67 & 0.26 & 3.10 & 140 & 53.33 & 531 \\
18 & 1.02 & 0.40 & 3.52 & 60 & 80 & 150 \\
24 & 1.34 & 0.50 & 3.80 & 15 & 95 & 30 \\
\hline
\end{tabular}




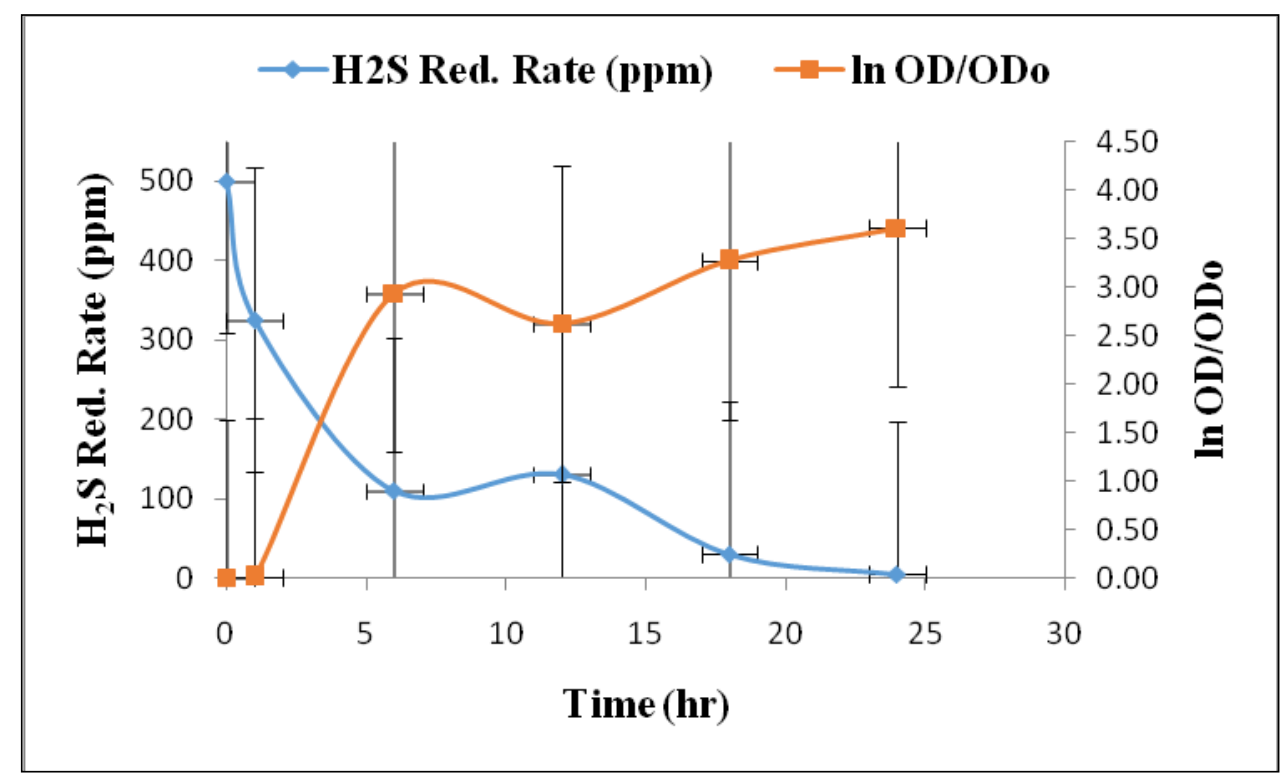

Figure 3: B. cereus (ATCC 14579) Growth \& Removal in 500 ppm Sulfide Concentration

Table 3: Growth \& Sulfide oxidation of Bacillus cereus (ATCC 14579) at $500 \mathrm{ppm}$

\begin{tabular}{|c|c|c|c|c|c|c|}
\hline Time & $\begin{array}{c}\text { OD (600 } \\
\mathrm{nm})\end{array}$ & $\begin{array}{l}\text { Cell dry wt } \\
(\mathrm{g} / \mathrm{L})\end{array}$ & $\begin{array}{l}\text { Expon. Cell growth } \\
(\operatorname{lnOD} / \mathrm{ODo})\end{array}$ & $\begin{array}{c}\mathrm{H}_{2} \mathrm{~S} \text { Red. Rate } \\
(\mathrm{ppm} / \mathrm{hr})\end{array}$ & $\begin{array}{c}\mathrm{H}_{2} \mathrm{~S} \text { removal } \\
(\%)\end{array}$ & $\begin{array}{l}\mathrm{ppm} \mathrm{H}_{2} \mathrm{~S} / \mathrm{g} \\
\text { cell }\end{array}$ \\
\hline 0 & 0.04 & 0.01 & 0.00 & 500 & 0.00 & 0.00 \\
\hline 1 & 0.03 & 0.01 & 0.01 & 325 & 35 & 32,500 \\
\hline 6 & 0.75 & 0.29 & 2.93 & 110 & 78 & 380 \\
\hline 12 & 0.55 & 0.21 & 2.62 & 130 & 74 & 620 \\
\hline 18 & 1.05 & 0.41 & 3.27 & 30 & 94 & 73 \\
\hline 24 & 1.48 & 0.58 & 3.61 & 5.0 & 99 & 8.0 \\
\hline
\end{tabular}




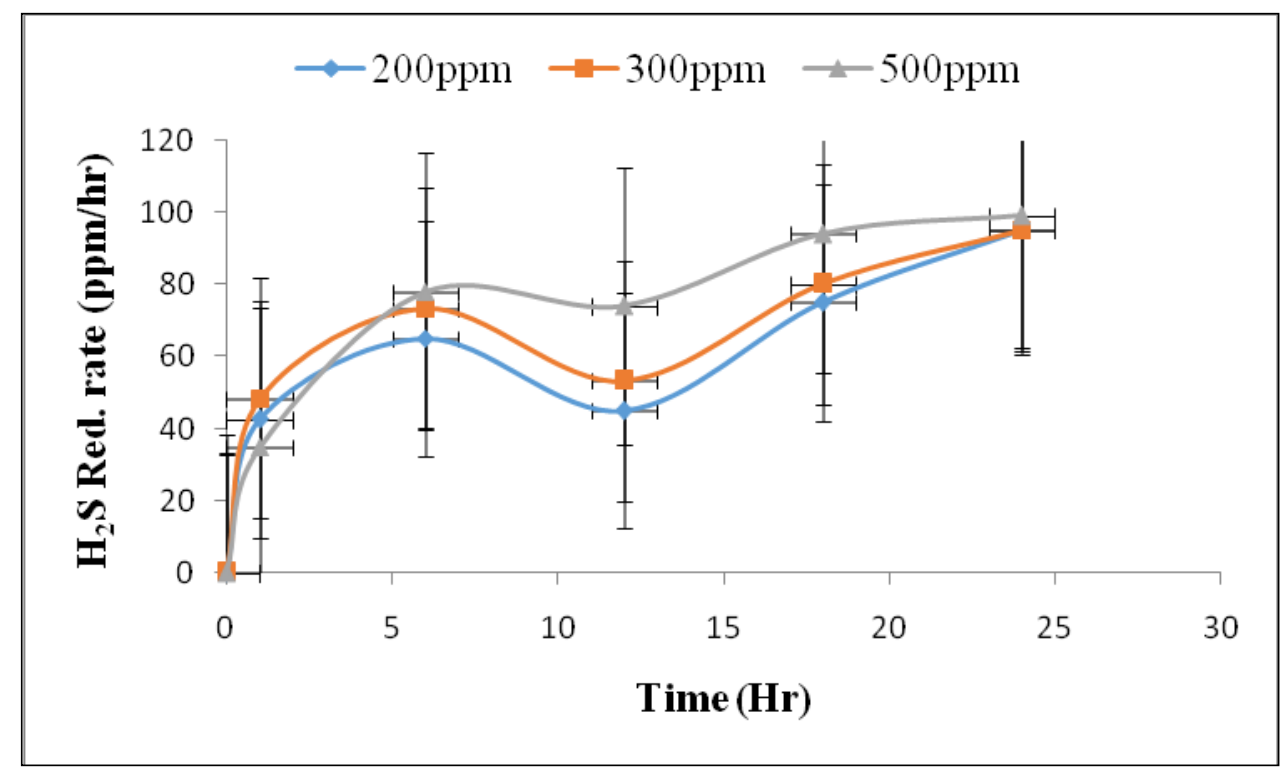

Figure 4: Sulfide Removal Rate at Different Concentration over 24 hour Period

Effect of sulfide bioxidation on bacterial cell biomass synthesis (cell dry weight)

Figures 5-7, showed the finding of B. cereus (ATCC 14579) cell dry weight (CDW) in $\mathrm{g} / \mathrm{L}$, which is ideally supposed to be 0.39 the value of OD $600 \mathrm{~nm}$. The trend in bacterial cell biomass synthesis is better explain by a calibration curve which is indicated by plotting OD against the CDW. The linear pattern of the plots from this finding fitted well to the supposedly relationship between amounts of light absorbance measured at wavelength $(600 \mathrm{~nm})$ of optical density and the increase in cell biomass over time also measured as cell dry weight. Based on the scatter plots; the regression expressed by correlation coefficient (R-squared) value of 0.9998, 0.9987 and 0.9999 were estimated for cell biomass increase at $200 \mathrm{ppm}, 300 \mathrm{ppm}$ and $500 \mathrm{ppm}$, respectively. This result is further strengthened by equation line of best fit, from which the average percentage of OD value that corresponds to maximum CDW $(y)$ could be established. In all the results; cell dry weight was observed to be directly proportional to optical density value. This finding was upheld by Azoddein, et al. (2015). It can be concluded that, all the model equations fitted well, indicating a significant positive correlation between cell biomass with optical density in an ascending order of $0.61 \mathrm{~g} / \mathrm{L}, 0.58 \mathrm{~g} / \mathrm{L}$ and $0.5 \mathrm{~g} / \mathrm{L}$ in $200 \mathrm{ppm}$, $500 \mathrm{ppm}$ and $300 \mathrm{ppm}$, respectively. 


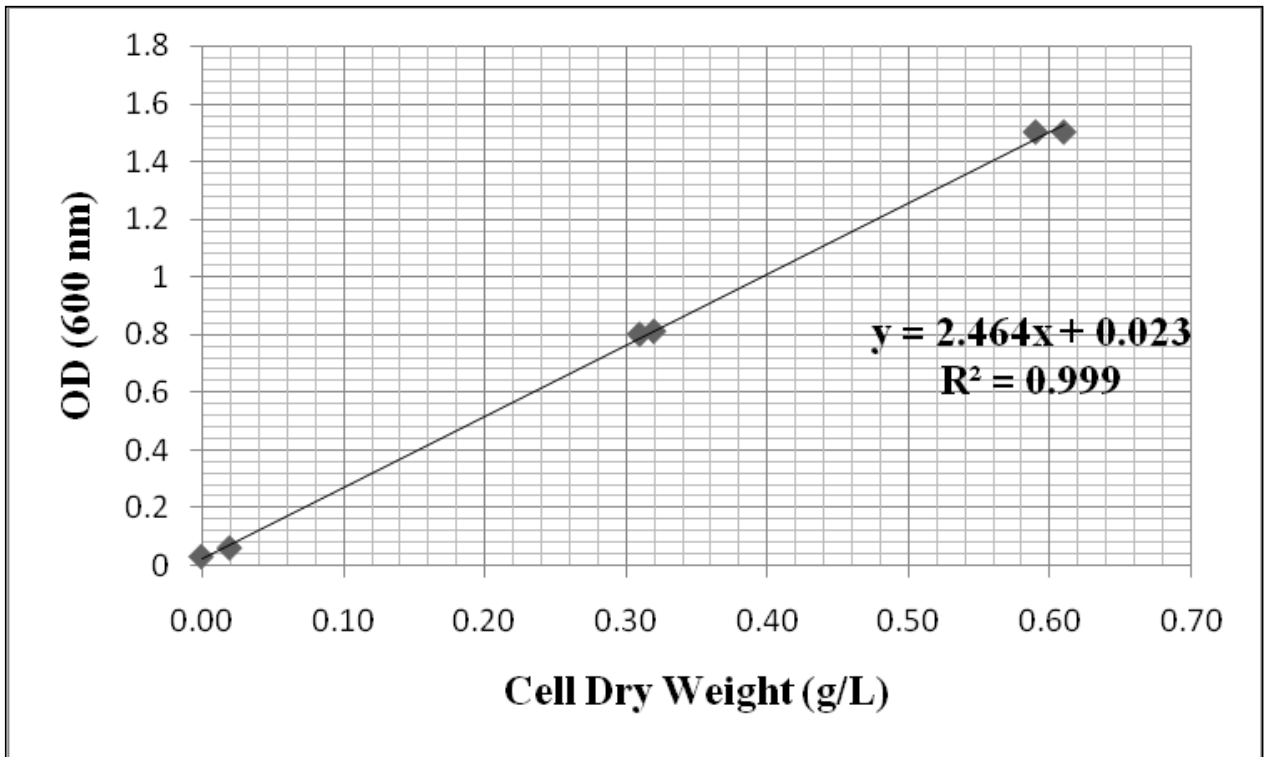

Figure 5: Bacterial cell dry weight curve in 200 ppm sulfide concentration

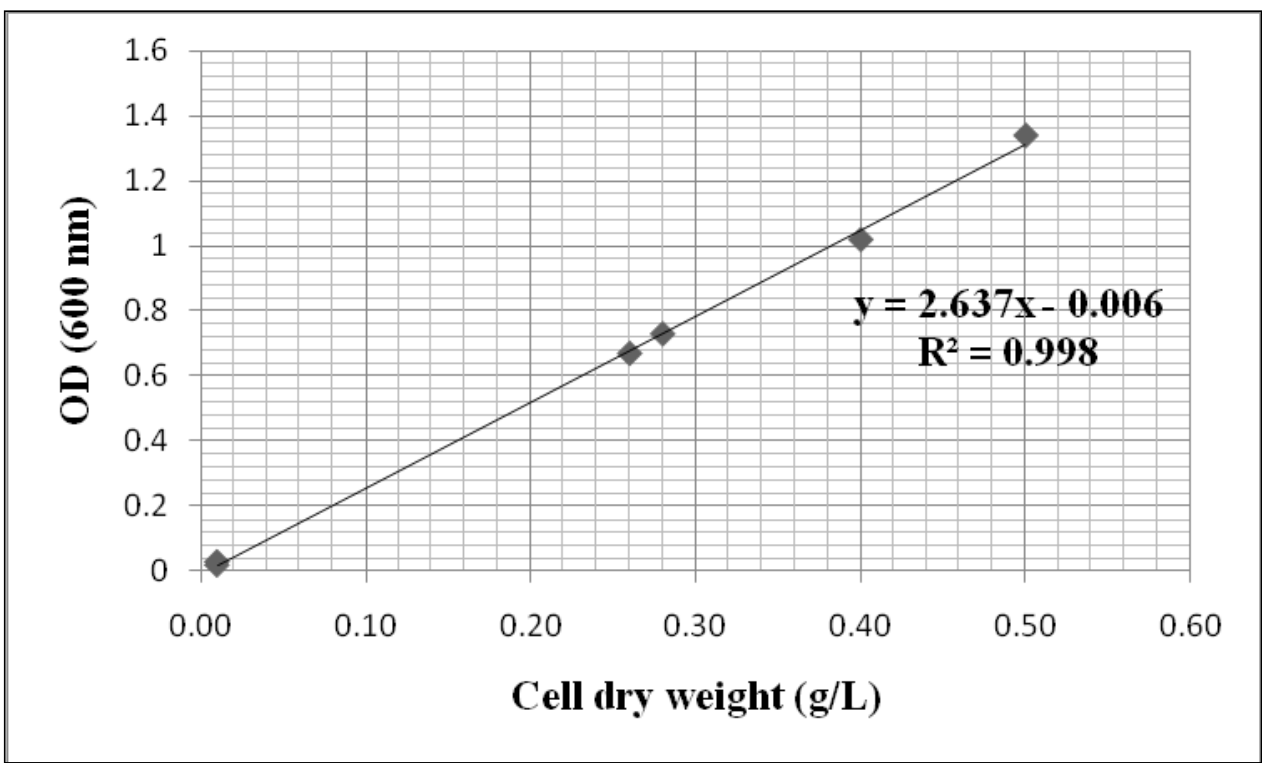

Figure 6: Bacterial cell dry weight curve in 300 ppm sulfide concentration 


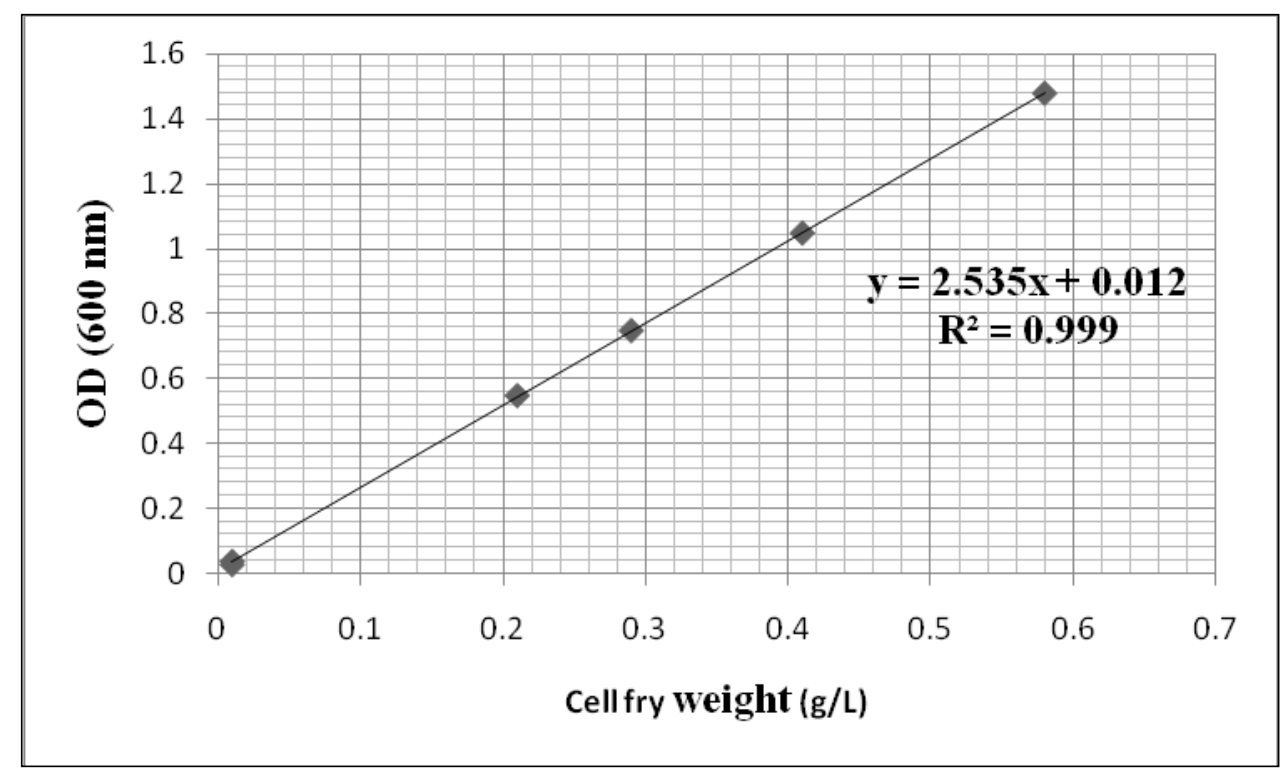

Figure 7: Bacterial cell dry weight curve in 500 ppm sulfide concentration

\subsection{CONCLUSIONS}

Bacillus cereus (ATCC 14579), has been known for its biodegradability potential of both domestic and refractory industrial wastewater. But its application directly to sulfide oxidation was not so much popular. The findings from this research have further confirmed the suitability of this strain in bioremediation process. Although, the condition under which this experiment was carried out was with limited oxygen availability, yet this inoculum was able to utilize and reduce sulfide at three different loading rates by almost $99 \%$ in 500 ppm sulfide, $95 \%$ in 300 ppm and $200 \mathrm{ppm}$, within 24 hour period respectively. Furthermore, this strain displayed its reliability in reducing sulfide level within the first six hours by $78 \%$ in 500 ppm, $73 \%$ in 300 ppm and $65 \%$ in $200 \mathrm{ppm}$, respectively. On the other hand, overall cell exponential growth was contrastingly higher in $200 \mathrm{ppm}$ with 3.91 , followed by $3.80300 \mathrm{ppm}$ and $3.61 \mathrm{in} 500 \mathrm{ppm}$. While bacterial cell dry weight followed the same pattern with $0.61 \mathrm{~g} / \mathrm{L}, 0.58 \mathrm{~g} / \mathrm{L}$ and $0.50 \mathrm{~g} / \mathrm{L}$ in 200 ppm, $500 \mathrm{ppm}$ and $300 \mathrm{ppm}$, respectively. But the reason behind this abnormal trend was not quite understood. Although it was probably due to limited inhibitory effect of sulfide, which allowed for faster growth in $200 \mathrm{ppm}$, over the other ranges, since it is the only varying limiting factor.

\section{ACKNOWLEDGEMENT}

Authors wishes to acknowledge the management of University Malaysia Pahang (UMP) for their financial support through local research grant (RDU), as well as the Faculty of Chemical and Natural Resources Engineering (FKKSA), for their technical support during the research period.

\section{REFERENCES}

Alcántara, S., Velasco, A., Muñoz, A., Cid, J., Revah, S., \& Razo-Flores, E. (2004). Hydrogen Sulfide Oxidation by a Microbial Consortium in a Recirculation Reactor System: Sulfur Formation under Oxygen Limitation and Removal of Phenols. Environmental Science and Technology, 38(3), 918-923. http://doi.org/Doi $10.1021 /$ Es034527y 
Azoddein, A.A., Ahmad, M.M., Yunus, R.M., \& Seman, M.N. (2016). A Bioremediation Approach to Mercury Removal in a Shake Flask Culture Using Pseudomonas putida ( ATCC 49128 ). Journal of Analytical \& Bioanalytical Techniques, 7(3). http://doi.org/10.4172/2155-9872.1000312

Azoddein, A.A., M., Yunus, R. M., Meriam, N., \& Sulaiman, N. (2015). Mercury Removal from Actual Petroleum Based Industries Wastewater by P . putida in Membrane Bioreactor . Globalllluminators, 2, 313-330.

Borah, D., \& Yadav, R. N. S. (2014). Biodegradation of petroleum oil by a novel Bacillus cereus strain DRDU1 from an automobile engine. International Journal of Environmental Research, 8(4), 1287-1294.

Bratbak, G., \& Dundas, I. (1984). Bacterial dry matter content and biomass estimates. Applied and Environmental Microbiology, 48(4), 755-757.

Bujang, M., \& Ibrahim, Noor Azlina, A. a/l E. R. (2013). BIODEGRADATION OF OILY WASTEWATER BY PURE CULTURE OF Bacillus cereus. ARPN Journal of Agricultural and Biological Science, 8(2), 108-115.

Chung, Y. C., Huang, C., \& Tseng, C. P. (1996). Biodegradation of hydrogen sulfide by a laboratory-scale immobilized Pseudomonas putida CH11 biofilter. Biotechnology Progress, 12(6), 773-778. http://doi.org/10.1021/bp960058a

Diaz, I. Perez, S. I. Ferrero, E. M. Fdz-Polanco, M. (2011). Effect of oxygen dosing point and mixing on the microaerobic removal of hydrogen sulphide in sludge digesters. Bioresource Technology, 102(4), 3768-3775. http://doi.org/10.1016/j.biortech.2010.12.016

Emami, M., Mousavi, M. F., \& Barzegar, M. (2004). Determination of sulfide in spring and wastewater by a new kinetic spectrophotometric method. Journal of the Chinese Chemical Society, 51(3), 517-521. http://doi.org/10.1002/jccs.200400078

Enning, D., \& Garrelfs, J. (2014). Corrosion of iron by sulfate-reducing bacteria: New views of an old problem. Applied and Environmental Microbiology, 80(4), 12261236. http://doi.org/10.1128/AEM.02848-13

Fajardo, C., Mora, M., Fernández, I., Mosquera-Corral, A., Campos, J. L., \& Méndez, R. (2014). Cross effect of temperature, $\mathrm{pH}$ and free ammonia on autotrophic denitrification process with sulphide as electron donor. Chemosphere, 97, 10-15. http://doi.org/10.1016/j.chemosphere.2013.10.028

Greben, H. A., Maree, J. P., Eloff, E., \& Murray, K. (2005). Improved sulphate removal rates at increased sulphide concentration in the sulphidogenic bioreactor. Water $S A$, 31(3), 351-358. http://doi.org/10.4314/wsa.v31i3.5206

Alexander Galushko, (2015):

https://www.researchgate.net/post/Why_is_bacterial_density_measured_at_OD_60

Hornstra, L. M., De Vries, Y. P., Wells-Bennik, M. H. J., De Vos, W. M., \& Abee, T. (2006). Characterization of germination receptors of Bacillus cereus ATCC 14579. Applied and Environmental Microbiology, 72(1), 44-53. http://doi.org/10.1128/AEM.72.1.44-53.2006

Janssen, A. J. H., Lettinga, G., \& De Keizer, A. (1999). Removal of hydrogen sulphide from wastewater and waste gases by biological conversion to elemental sulphur. Colloidal and interfacial aspects of biologically produced sulphur particles. Colloids and Surfaces A: Physicochemical and Engineering Aspects, 151(1-2), 389-397. http://doi.org/10.1016/S0927-7757(98)00507-X

Kim, J. H., Rene, E. R., \& Park, H. S. (2008). Biological oxidation of hydrogen sulfide under steady and transient state conditions in an immobilized cell biofilter. Bioresource Technology, 99(3), 583-588. 
http://doi.org/10.1016/j.biortech.2006.12.028

Kleinjan, W. E., de Keizer, A., Janssen, A. J. H., Sinha, S., Raj, A., AlShoaibi, A. S., ... Marquaire, P.-M. (2005). Kinetics of the Reaction between Dissolved Sodium Sulfide and Biologically Produced Sulfur. Industrial \& Engineering Chemistry Research, 44(2), 377-384. http://doi.org/10.1021/es940691x

Kousi, P., Remoundaki, E., Hatzikioseyian, A., \& Tsezos, M. (2015). Sulphate-reducing bioreactors: current practices and perspectives. In IWA Balkan Young Water Professional, 2015, May 10-12, 2015 (pp. 409-417). Thessaloniki.

Krayzelova, L., Bartacek, J., Díaz, I., Jeison, D., Volcke, E. I. P., \& Jenicek, P. (2015). Microaeration for hydrogen sulfide removal during anaerobic treatment: a review. Reviews in Environmental Science and Biotechnology, 14(4), 703-725. http://doi.org/10.1007/s11157-015-9386-2

Krayzelova, L., Bartacek, J., Kolesarova, N., \& Jenicek, P. (2014). Microaeration for hydrogen sulfide removal in UASB reactor. Bioresource Technology, 172, 297-302. http://doi.org/10.1016/j.biortech.2014.09.056

Li, W., Zhao, Q. L., \& Liu, H. (2009). Sulfide removal by simultaneous autotrophic and heterotrophic desulfurization-denitrification process. Journal of Hazardous Materials, 162, 848-853. http://doi.org/10.1016/j.jhazmat.2008.05.108

Liang, Z., An, T., Li, G., \& Zhang, Z. (2015). Aerobic biodegradation of odorous dimethyl disulfide in aqueous medium by isolated Bacillus cereus GIGAN2 and identification of transformation intermediates. Bioresource Technology, 175, 563568. http://doi.org/10.1016/j.biortech.2014.11.002

Lorna Guerreroa, S. M., César, H., Luis, J. C., And, B. A., \& Rafael, B. (2015). Advances in the biological removal of sulphides from aqueous phase in anaerobic processes:A review. Environmental Review, (November), 1-61.

http://doi.org/10.1139/er-2015-0046

Mathew, A. (2014). BIODEGRADATION OF PHENOL-AEROBIC AND ANAEROBIC. International Journal of Science and Nature, 5(3), 366-387.

Mols, M., \& Abee, T. (2011). Primary and secondary oxidative stress in Bacillus. Environmental Microbiology, 13(6), 1387-1394. http://doi.org/10.1111/j.14622920.2011.02433.x

Moon, H. S., Ahn, K. H., Lee, S., Nam, K., \& Kim, J. Y. (2004). Use of autotrophic sulfur-oxidizers to remove nitrate from bank filtrate in a permeable reactive barrier system. Environmental Pollution, 129(3), 499-507.

http://doi.org/10.1016/j.envpol.2003.11.004

Mora, M., Fernández, M., Gómez, J. M., Cantero, D., Lafuente, J., Gamisans, X., \& Gabriel, D. (2014). Kinetic and stoichiometric characterization of anoxic sulfide oxidation by SO-NR mixed cultures from anoxic biotrickling filters. Applied Microbiology and Biotechnology, 99(1), 77-87. http://doi.org/10.1007/s00253-0145688-5

Mosquera, S., González-Jaramillo, L. M., Orduz, S., \& Villegas-Escobar, V. (2014). Multiple response optimization of Bacillus subtilis EA-CB0015 culture and identification of antifungal metabolites. Biocatalysis and Agricultural Biotechnology, 3(4), 378-385. http://doi.org/10.1016/j.bcab.2014.09.004

Nielsen, A. H., Vollertsen, J., \& Hvitved-Jacobsen, T. (2006). Kinetics and stoichiometry of aerobic sulfide oxidation in wastewater from sewers-effects of $\mathrm{pH}$ and temperature. Water Environment Research, 78(3), 275-283. http://doi.org/10.2175/106143005x94367

Nur Hafizah Azizana, Kasing Ak Apunb, Lesley Maurice Bilungb, Micky Vincentb, 
Hairul Azman Roslanb, A. A. S. A. A. H. (2016). CRUDE OIL BIOREMEDIATION BY INDIGENOUS BACTERIA ISOLATED FROM OILY SLUDGE. Jurnal Teknologi, 2, 61-66.

Schagger, H., Cramer, W. A., \& Vonjagow, G. (2004). Growth and Sporulation of Bacillus cereus ATCC 14579 under Defined Conditions: Temporal Expression of Genes for Key Sigma Factors. APPLIED AND ENVIRONMENTAL MICROBIOLOGY, 70(4), 220-230. http://doi.org/10.1128/AEM.70.4.2514

Schultz, D., \& Kishony, R. (2013). Optimization and control in bacterial lag phase. BMC Biology, 11(1), 120. http://doi.org/10.1186/1741-7007-11-120

Standbury, P.F., Whitaker, A. and Hall, S. J. (1984). P. of F. T. O. B. H. (1984). Principle of Fermentation. Standbury, P.F., Whitaker, A. and Hall, S. J. (1984). Principles of Fermentation Technology. Oxford: Butterworth Heinemann (2nd ed., Vol. 53). OXFORD: BUTTERWORTH HEINEMANN.

http://doi.org/10.1017/CBO9781107415324.004

Tang, K., Baskaran, V., \& Nemati, M. (2009). Bacteria of the sulphur cycle: An overview of microbiology, biokinetics and their role in petroleum and mining industries. Biochemical Engineering Journal, 44(1), 73-94. http://doi.org/10.1016/j.bej.2008.12.011

Van den Ende, F. P., \& Van Gemerden, H. (1993). Sulfide oxidation under oxygen limitation by a Thiobacillus thioparus isolated from a marine microbial mat. FEMS Microbiology Ecology, 13(1), 69-77. http://doi.org/10.1016/0168-6496(93)90042-6

Vinothini, C., Sudhhakar, S. and Ravikumar, R. (2015). Biodegradation of petroleum and crude oil by Pseudomonas putida and Bacillus cereus. International Journal of Current Microbiology and Applied Sciences, 4(1), 318-329.

Wang, X., Zhang, Y., Zhang, T., \& Zhou, J. (2016). Effect of dissolved oxygen on elemental sulfur generation in sulfide and nitrate removal process: characterization, pathway, and microbial community analysis. Applied Microbiology and Biotechnology, 100(2895-2905), 1-11. http://doi.org/10.1007/s00253-015-7146-4

Zhou, W., Sun, Y., Wu, B., Zhang, Y., Huang, M., Miyanaga, T., \& Zhang, Z. (2011). Autotrophic denitrification for nitrate and nitrite removal using sulfur-limestone. Journal of Environmental Sciences, 23(11), 1761-1769. http://doi.org/10.1016/S1001-0742(10)60635-3

Zytoon, M. A.-M., AlZahrani, A. A., Noweir, M. H., \& El-Marakby, F. A. (2014). Bioconversion of high concentrations of hydrogen sulfide to elemental sulfur in airlift bioreactor. Hindawi Publishing Corporation; The Scientific World Journal, 2014, 675673. http://doi.org/10.1155/2014/675673 